Review

\title{
Agricultural Sector of Bosnia and Herzegovina and Climate Change-Challenges and Opportunities
}

\author{
Ognjen Zurovec *, Pål Olav Vedeld and Bishal Kumar Sitaula \\ Department of International Environment and Development Studies (Noragric), \\ Norwegian University of Life Science (NMBU), Universitetstunet 31430 Ås, Norway; \\ E-Mails: pal.vedeld@nmbu.no (P.O.V.); bishal.sitaula@nmbu.no (B.K.S.) \\ * Author to whom correspondence should be addressed; E-Mail: ognjen.zurovec@nmbu.no; \\ Tel.: +47-67-231344.
}

Academic Editor: Terence Centner

Received: 9 February 2015 / Accepted: 5 May 2015 / Published: 12 May 2015

\begin{abstract}
Half of Bosnia and Herzegovina's (BH) population lives in rural areas. Agricultural production is a backbone of the rural economy and generates significant economic value for the country. $\mathrm{BH}$ is highly vulnerable to climate change, which poses a significant development challenge given the climate-sensitivity of the agricultural sector, the share of agriculture in the total economy, the number of people employed in the sector, and the closely related socio-economic issues of food security. $\mathrm{BH}$ has experienced serious incidences of extreme weather events over the past two decades, causing severe economic losses. Based on available data and currently available climate projections, exposure to threats from climate change will continue to increase. The review paper presents the current state of the BH agricultural sector and the impact of potential climate change on agricultural systems. It proposes policy options to optimize opportunities and mitigate consequences of possible climate change in the agricultural sector. Development of policy and research capacity should include harmonisation and centralisation of domestic agricultural policies, carrying out a vulnerability assessment and strengthening the public and private extension systems. Further technological development should include improvements in weather and climate information systems, crop development, irrigation and water management.
\end{abstract}

Keywords: Bosnia and Herzegovina; agriculture; climate change; adaptation 


\section{Introduction}

Bosnia and Herzegovina $(\mathrm{BH})$ belongs to a group of countries considered highly vulnerable to climate change [1,2]. Agriculture is an important and vulnerable economic sector in $\mathrm{BH}$, given the climate-sensitivity of the sector, the share of agriculture in the economy ( $7 \%$ of the GDP), the number of people employed in the sector, and the closely related socio-economic issues of food security [3].

Climate change leads to adaptation among farmers and their agricultural production in the affected areas. However, adaptation does not occur independently, but rather as a process influenced by socio-economic, political, cultural, geographical, ecological and institutional factors [4,5]. Adequate responses will depend on the ability of decision makers, from the farm level to the national policy level, to perceive climate change and to take relevant action. The current state of politics in Western Balkan countries (WBC), where the public sector is mostly silent and non-transparent, and where the scientific contributions on climate change analyses are scarce, has led to limited development of activities in this field. It therefore comes as no surprise that climate change policy issues are not visible at any level of the policy-making agenda in these countries. As a result, climate change is not treated seriously in current published key strategic documents. One of the main problems comes from inadequate social and human capital when it comes to the introduction and implementation of measures and policies. However, there is a gradual rise of awareness in WBC about climate change, its importance and impact on all spheres of life $[3,6-8]$.

The general objective of this review paper is to present the current state of the agricultural sector in $\mathrm{BH}$ and the impact of climate change on agricultural systems in $\mathrm{BH}$. The first section of this paper gives an overview of BH's agricultural sector and its significance, together with the challenges and possible opportunities. The second section assesses the impact of climate change to BH's agricultural sector based on both current conditions and future predictions. The first two sections are based on data derived from official statistical releases, national and international reports and other relevant literature. In the last section, we propose policy options based on the international literature to optimize opportunities and mitigate consequences of climate change in the agricultural sector, in order to increase productivity and adapt agriculture in $\mathrm{BH}$ to changing climate.

\section{Overview of Agricultural Sector in Bosnia and Herzegovina}

$\mathrm{BH}$ was considered as a raw material-energy providing region, of the former Yugoslavia throughout the major part of the last century [9]. In the constitutional order of Yugoslavia, BH was part of the federation of six autonomous republics, ruled by a strong central government under the control of the Communist Party. Therefore, the development path and policies cannot be attributed to individual republics only, but external decisions taken at higher levels were crucial in policy formulation and outcome processes [10]. The natural resources of BH are the country's great fortune and misfortune at the same time, which was historically recognised by a large number of occupier exploiting these resources throughout the course of history. Prior to the Second World War, BH was a particularly undeveloped agrarian country compared to its western neighbours. Agriculture was the main sector of the economy during post-war reconstruction. However, at the same time, the foundations of the industrial 
development, exclusively related to potential in raw materials, were established. Industry employed only $2 \%$ of the total population prior to this period [11].

The main characteristics of the former BH economy and national planning is economic development based on the example of post-revolutionary Soviet Russia [9,12], which preferred development of heavy industry as a prerequisite for the development of light industry, transport and agriculture [13]. The leading industries were in metallurgy and chemical industry. The industry employed $54.3 \%$ of the entire population in 1961, reached its peak in 1981 (58.4\%), and was 44\% in 1991, after which comes a new period of war. Industrialization was the key cause of de-agrarian processes, which left deep impacts on social structures in rural areas. The share of agricultural population has decreased $76 \%$ in a 40 -year period (1948-1981) [14]. BH experienced industrialization that initiated an urban development and migration to urban areas, de-populating rural areas. Agricultural resources as a public good have not been seen in accordance with general social interest - large areas of arable land have been left abandoned and uncultivated [15]. This, among other factors, led to a situation where the country could meet barely $50 \%$ of its needs for food [16].

One of the main revolutionary convictions of the newly established socialist state was that the inherited capitalist model of ownership and property rights was seen as a cause of social injustice and inequality. The new government attempted to achieve their vision of social equality and justice through the introduction of common ownership [17]. This was accomplished through adoption of laws and regulations that abolished private properties as the predominant form. At this time, important economic and industrial facilities were converted to state property through confiscation, sequestration, agrarian reforms and nationalization. Land as a common ownership was acquired primarily by confiscation of assets from persons convicted as "enemies of the state" and then significantly increased through agrarian reforms in 1945 and 1953. Agrarian reforms abolished large private land holdings and limited them to a maximum of 10 ha per private entity $[17,18]$. The confiscated land was awarded to landless peasants and farmers with insufficient land. This led to the emergence of a large number of small and medium sized farms with a tendency of further fragmentation. The agrarian reforms set back agricultural production almost to a scenario of natural or subsistence economy [9]. In addition, the remaining agricultural production was plagued by weak capital equipment of family farms [19] and obsolete technologies [20]. A shift in agricultural policies was recorded in the 70s, where much attention was paid to the development of agriculture and rural areas. The plan was to increase the intensity of production through higher yields and general increased productivity. Investment in land amelioration was one of the focus areas of this master plan. In the 80s, Yugoslavia was plunged into a deep economic crisis, which has affected investments in agriculture and the effective implementation of the planned investment programs.

Like all other sectors, the agricultural sector has suffered enormous damage during the war period (1992-1995). The programs of reconstruction and restoration of international donors focused on basic rural infrastructure and housing, purchase of agricultural machinery and inputs, seeds and fertilizers for the reconstruction and rehabilitation of crop production. It was more of a social aid to local people than a serious investment in the revitalization of agriculture, with the main objective to return displaced population in rural areas [21].

Today, $\mathrm{BH}$ is still a predominantly rural country. It is estimated that about $61 \%$ of the population live in rural areas [22]. Although the share of agriculture in GDP is constantly decreasing (11\% in 2003 to 
$7 \%$ in 2013), agricultural production is a backbone of the rural economy, employing $20 \%$ of workforce. The economy of $\mathrm{BH}$ demonstrated considerable vitality by achieving high growth rates, especially in 2009 , but it was not enough to significantly approach the level of medium developed countries. Actual GDP per capita in 2011 was only 30\% of the EU 27 average and reached only $80 \%$ of GDP of which it had in 1989 [23]. BH's decentralized political and administrative structure is very complex. This unique constitutional order involves two entities: Federation of BH (FBiH) and Republika Srpska (RS), as well as the Brcko District of BH (BD), as separate administrative units. In addition, $\mathrm{FBiH}$ is divided into 10 Cantons. This complex governance structure also has a great impact on management competence and capacity in the agricultural sector. The situation in the agricultural sector in $\mathrm{BH}$ is featured by different regulations at different levels, legislative overlaps, limited capacities and communication channels, as well as a lack of clear vision and failure to implement necessary reforms. The legacy of the past socio-political system, coupled with the current complex political structure, have significant consequences for agricultural development, facing many challenges.

\subsection{Agricultural Productivity}

The main problem of the agricultural sector is low productivity, both per unit of production, and per farm [8]. The main feature is small-scale, subsistence agriculture oriented production rather than a more commercial or market oriented agro-food system. It is a main cause of low competitiveness, particularly in the domestic market. Low agricultural productivity is often a consequence of the absence of clear specialization, primarily in crop production, low technology levels of farms and extreme dependence on weather conditions. Shifts in terms of improving productivity are apparent, however, these processes are very slow [24]. The main reasons for a slow process of improving productivity are difficult and risky market access, and insufficient capacity for storing and processing, especially vegetables. In addition, production of seed material, nurseries and seedlings is underdeveloped and the production depends on imported seeds, often with questionable quality and without adequate control [8]. The level of technological and marketing knowledge among producers is low, which certainly has a negative effect on the productivity of the sector. The main cause for low production of basic agricultural products is that in the previous years, existing agricultural capacities have not been used intensively. Agricultural land covers 2.1 million hectares, of which $46.5 \%$ is arable (Table 1) and as much as half of arable land remains unused (Figure 1).

Table 1. Structure of agricultural land in Bosnia and Herzegovina. Source: [25].

\begin{tabular}{ccc}
\hline Category & Area $(\mathbf{0 0 0}$ ha) & $\mathbf{\%}$ \\
\hline Arable land & 1004.9 & 19.6 \\
Orchards & 99.4 & 1.9 \\
Vineyards & 5.6 & 0.1 \\
Meadows & 460.2 & 9.0 \\
Pastures & 588.2 & 11.5 \\
\hline Total Agricultural Land & $\mathbf{2 1 5 8 . 3}$ & $\mathbf{4 2 . 2}$ \\
\hline Forests & $2,795.1$ & 54.6 \\
Other & 166.3 & 3.2 \\
Total & $\mathbf{5 1 1 9 . 7}$ & $\mathbf{1 0 0 . 0}$ \\
\hline
\end{tabular}




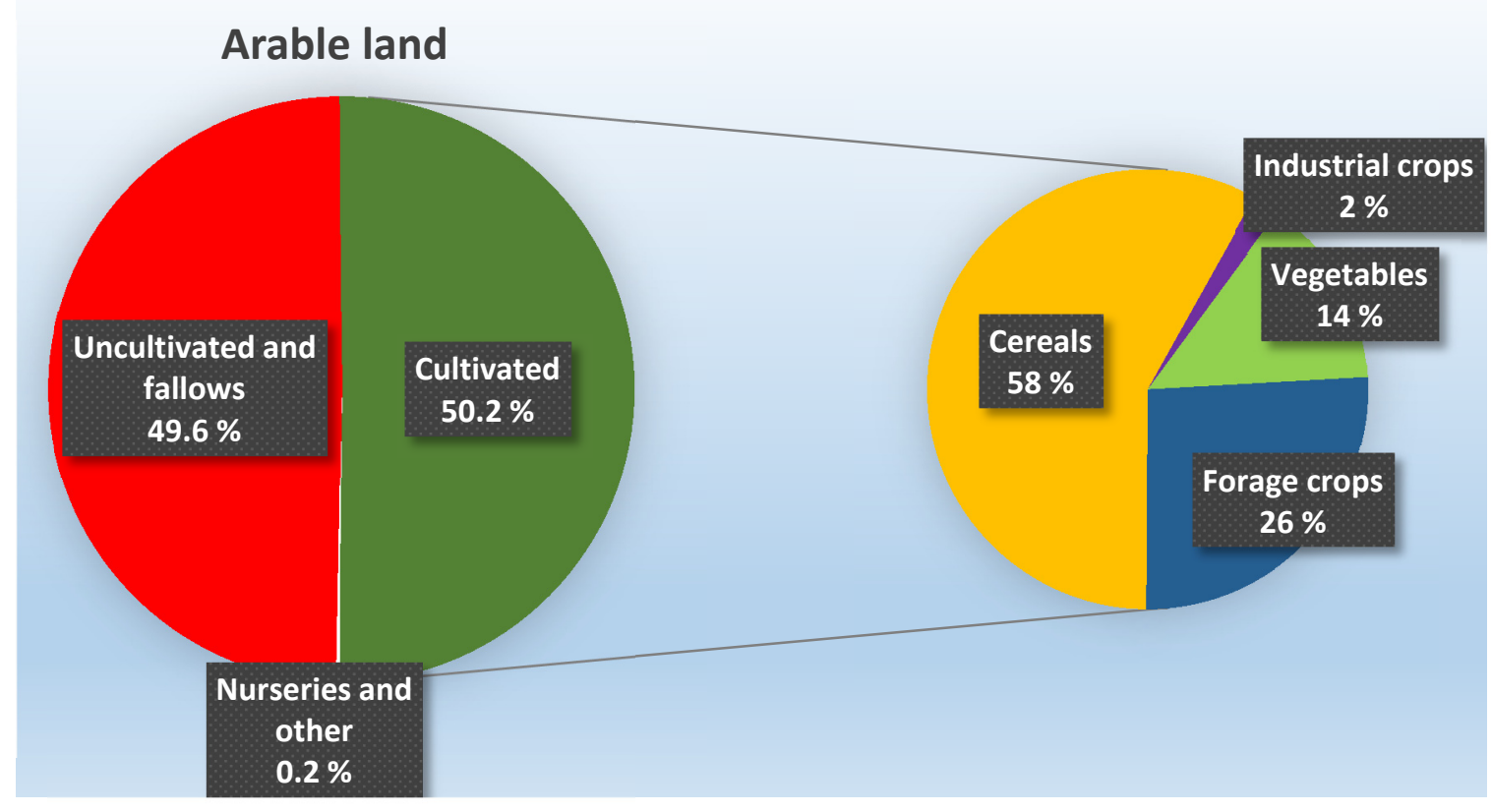

Figure 1. Structure of arable and cultivated arable land. Source: [26].

\subsection{Livestock Production}

Livestock production has a great significance for $\mathrm{BH}$ agriculture considering the available natural resources and the number of people engaged in this production. The key products from livestock involve milk and dairy products, meat and meat products. Since the number of livestock stagnated or declined in recent years, except in the case of poultry (Figure 2), growth in production of meat and milk is explained by improvements in yields and breed composition, but productivity is still low compared with countries in the region [22]. Low productivity is certainly partly due to still inadequate breed structure, inefficient breeding and selection work, but mostly because of the duality in production [8]. Extensive production on small farms is prevailing in livestock production, while on the other hand a small part of the production is organized on the modern, technologically well-equipped farms. While there has been some progress in exports and productivity in recent years, the overall competitiveness of livestock production in the international markets is still weak. BH currently achieves only a small share of imports in its major export destinations, mainly the Western Balkan countries [27]. One of the largest problems in livestock production is the banned on export of Products of Animal Origin to EU. For many years, EU has been requesting the establishment and reorganisation of control system for food and animal stock feed, based on the principle "From Farm to Fork". However, this issue has not been resolved, due to disagreements and lack of coordination and cooperation between the state and entity level institutions in the food safety system and it remains unclear when it will be addressed [28]. 


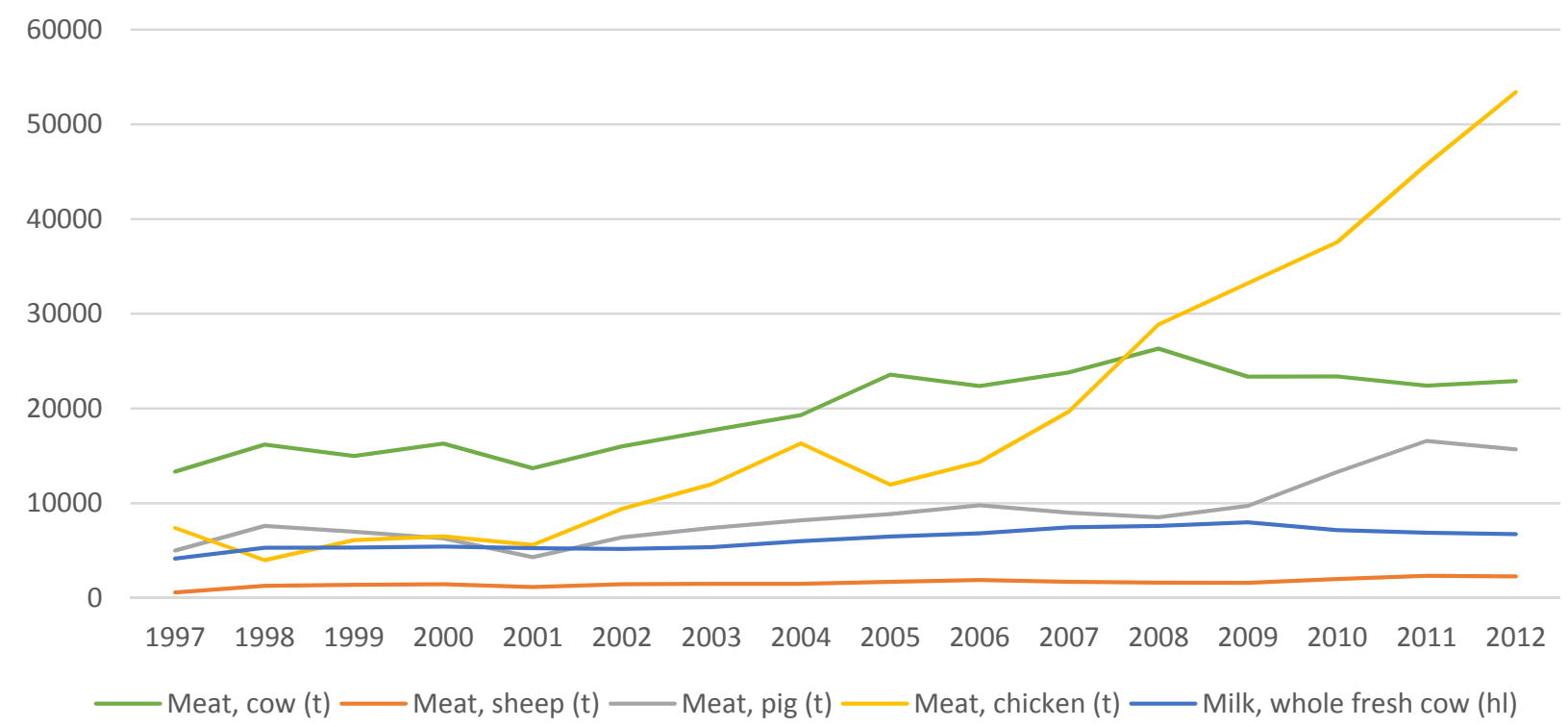

Figure 2. Meat and milk production in Bosnia and Herzegovina. Source: [29].

\subsection{Crop Production}

Despite relatively favourable natural conditions, crop production is facing many challenges. Frequent adverse weather conditions in key stages of crop growth (high or low temperatures, late spring or early autumn frosts, deficit or surplus rainfall) are further aggravated by lack of farm investment, high prices and poor quality of inputs (such as seeds, fertilizers, and pesticides), subsistence agriculture and traditional extensive farming practices. The result is low productivity and significantly lower yields compared with the rest of the region (Figure 3).

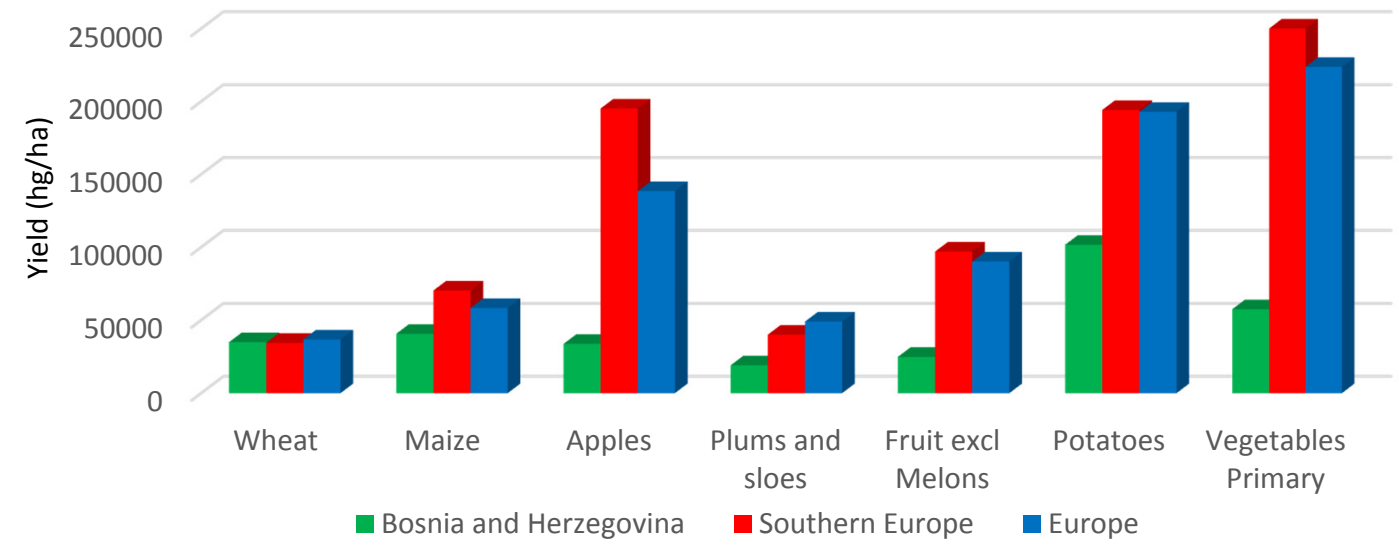

Figure 3. Yield comparison for most important crops in Bosnia and Herzegovina with the regional production. Source: [29].

Cereals dominate agricultural crop production areas (Figure 1), with maize as the main crop (more than $60 \%$ of total cereal production). Domestic production of cereals in $\mathrm{BH}$ is not sufficient to meet the total consumption demands [22]. The yields of forage crops are low and well below their genetic potential. Resulting feed has a low protein and high cellulose percentage, despite the usage of high 
quality legumes and their mixtures [30]. Hay yields on grasslands are even lower since most of them are not managed at all. Vegetable production is mainly focused on local markets and takes place in mixed farming systems, often as a supplementary source of income. Orchards and vineyards in BH suffered enormous damage during the war and are currently going through a phase of consolidation and regeneration. Plums, apples and pears dominate the production [26].

\subsection{Farm Structure}

The exact number of agricultural holdings, particularly family farms, is not known, since a census of agriculture that would provide a comprehensive picture of the structure of agricultural holdings has not been conducted since 1960. This includes determining and typologically categorising farms in relation to the utilized agricultural area (UAA), and determining the size of farms according to UAA. The general characteristic of the Western Balkans' agriculture is that the majority of the producers are smallholders. The main reason for this situation is the former Yugoslavian agricultural policy (farm size limit 10 hectares) [17,18]. Beside its low size (4.7 ha/farm), in most cases farms are formed from small parcels, often dislocated from each other, which makes the production more costly and less efficient., Some 250.000 farms $(50 \%)$ are less than 2 hectares, and 400.000 or $80 \%$ are less than 5 hectares, while only $4 \%$ have areas beyond 10 hectares [31].

\subsection{Agrarian Policy}

The budget allocation to agriculture is quite low compared to developed and even developing countries amounting to about $2 \%$ of total public spending in 2007 [32]. By looking at the structure of agricultural support by groups of measures, it is noticeable that the largest amount of support during the analysed period was within the framework of direct payments to producers, which refers to payments based on output and the payment per unit area/cattle. The current BH policy resembles the EU policy in the mid-80s, which will not directly promote productivity increases in BH's agriculture. Budgetary transfers related to direct support to producers and payments based on output form more than $40 \%$ of the total agricultural budget [8]. This means that the composition of subsidies in BH is heavily oriented toward direct production rather than investments. Taking into account that most of the smallholder farmers orient their production towards subsidized crops or livestock in order to have access to an additional source of income, this form of support has the function of a social transfer rather than providing productive support to the agriculture sector [32]. The biggest difference between the agrarian policy of BH and the EU's Common Agricultural Policy (CAP) is that CAP has moved away from subsidies tied to production-unbound payments per unit area/cattle/revenue/income and is gradually moving toward investment grants (through Pillar II).

\subsection{Agricultural Markets}

Inadequate market access reduces the motivation of farmers to specialize and improve their performance and to increase production. Because of the fragmented agricultural production, one of the most important channels for agricultural outputs, the food industry, is not motivated to link up with agricultural producers on long-term contracts [22]. In addition, the current weak food industry is not able 
to take the role of being the main driver or vehicle of vertical connectivity for an efficient value chain. Consequently, the industry is not interested in improving the present value chain; it uses its negotiating powers and often does not respect agreements made. On the other hand, horizontally disjointed and disorganized producers, who since the time of socialism have expectations that the food industry has an additional social task - the purchase of produced foods - do not offer/respect contract quantities, and often do not deliver adequate quality [8]. The producers do not use the opportunity to develop its regional identity through the production of products with geographical origin, originality or traditional products. In other words, the product range is very narrow, and all companies operate within a narrow segment of the market, while the rest of the niche markets are left to import companies. That is why the food industry companies are faced with stiff competition within the domestic market, and a large number of companies are not able to independently adopt the standards required for foreign markets.

\subsection{Agricultural Extension}

The networks of public and private institutions, organizations and research institutions, which rely on a system of life-long education, efficient transfer of knowledge, technology and information, form a potential base for innovation and modernization, but they are not established or are severely underdeveloped. The informal sector and NGOs activities, which are implementing different, usually internationally funded, development projects, had a significant role in the transfer of technology in the previous period. These projects have launched initiatives for the establishment of private advisory services, as well as building a portal for the exchange and dissemination of various types of information, which upon completion of the project are either forgotten or unsustainable, because the system cannot become part of the technology transfer system [8]. The core of knowledge and technology transfer services is meant to go through the public extension service. The public extension services, which are located at the regional or cantonal ministries, depending on the entity, mainly perform administrative work and devote very little time to field related work. Coordination between regional extension services do not exist, nor does a systemic approach to their strengthening (especially education) and equipping. This results in a very slow technological progress in the sector compared to the agricultural sectors in neighbouring countries, which ultimately leads to a deepening of the technological and knowledge gap.

\subsection{Trade Imbalance}

Generally, relatively negative macroeconomic trends are the result of high foreign trade imbalance and high trade deficits, which are the main causes of the negative current account balance. Although the relative share of the negative trade balance in GDP is decreasing-from 31.9\% (2006) to 28.4\% (2011) - it is still unsustainably high [8]. Such a high negative trade balance is significantly affected by import of agri-food products (18.3\% in 2012). Despite that BH has signed a large number of bilateral and multilateral agreements with neighbouring countries, existing inefficient trade policy mechanisms have not lead to a significant increase in exports of agriculture and food products [22]. At the same time, the agricultural sector faces many other challenges, especially in the part of the fulfilment of obligations towards the European Union, since joining inevitably requires adjustment and reform of the agricultural sector in line with EU requirements. 


\section{Bosnia and Herzegovina and Climate Change}

$\mathrm{BH}$ is a mountainous country with lowlands along the banks of major rivers. Moving from north to south, the flat landscape gradually becomes wide foothills, arising from 200-600 m above sea level, and gradually turns into a mountainous region. The rest of the area is dominated by the Dinaric Alps, which extend across the whole country, from the western border with Croatia towards the southeast. The central part consist of hills among which are relatively broad river valleys and basins. Karst (barren rocky) terrains cover most of the south-western territories of $\mathrm{BH}$.

As part of the general circulation of the atmosphere over the Balkans, and thus over $\mathrm{BH}$, there are frequent shifts of tropical air masses during summer and the inflow of cold arctic air during winter. All these processes are largely modified by relief that occurs as a major climate modifier. For this reason, the territory of BH is split between three main types of climate: (1) Continental and moderate-continental (2) Mountain and mountain-depression; and (3) Mediterranean and modified Mediterranean climate [3,33]. Continental climate occurs in the north, the Mediterranean to the south, and the line that separates these two regions is dominated by high mountains, plateaus and cliffs which are, depending on the altitude, affected by the mountain climate.

\subsection{Future Climate Change Scenarios}

$\mathrm{BH}$ has experienced serious incidences of extreme weather events in the past two decades, causing severe economic losses. Based on available data and currently available climate projections, exposure to threats from climate change will continue to increase [33]. Observed climate changes are reflected through an increase in average temperatures in $\mathrm{BH}$. For the last hundred years, the average temperature has increased by $0.8^{\circ} \mathrm{C}$ (which is in line with global trends), with a tendency to accelerate - the decade of 2000-2010 is warmest in the last 120 years. According to IPCC SRES's scenarios based on SINTEX-G and ECHAM5 climate models (Figure 4), the mean seasonal temperature changes for the period 2001-2030 are expected to range from $+0.8{ }^{\circ} \mathrm{C}$ to $+1.0{ }^{\circ} \mathrm{C}$ above previous average temperatures [3]. Winters are predicted to become warmer (from $0.5^{\circ} \mathrm{C}-0.8^{\circ} \mathrm{C}$ ), while the biggest changes will be during the months of June, July and August, with predicted changes of $+1.4{ }^{\circ} \mathrm{C}$ in the north and $+1.1{ }^{\circ} \mathrm{C}$ in southern areas. Precipitation is predicted to decrease by $10 \%$ in the west of the country and increase by $5 \%$ in the east. The autumn and winter seasons are expected to have the highest reduction in precipitation. Further significant temperature increases are expected during the period 2071-2100, with a predicted average rise in temperature up to $4{ }^{\circ} \mathrm{C}$ and precipitation decrease up to $50 \%$. 

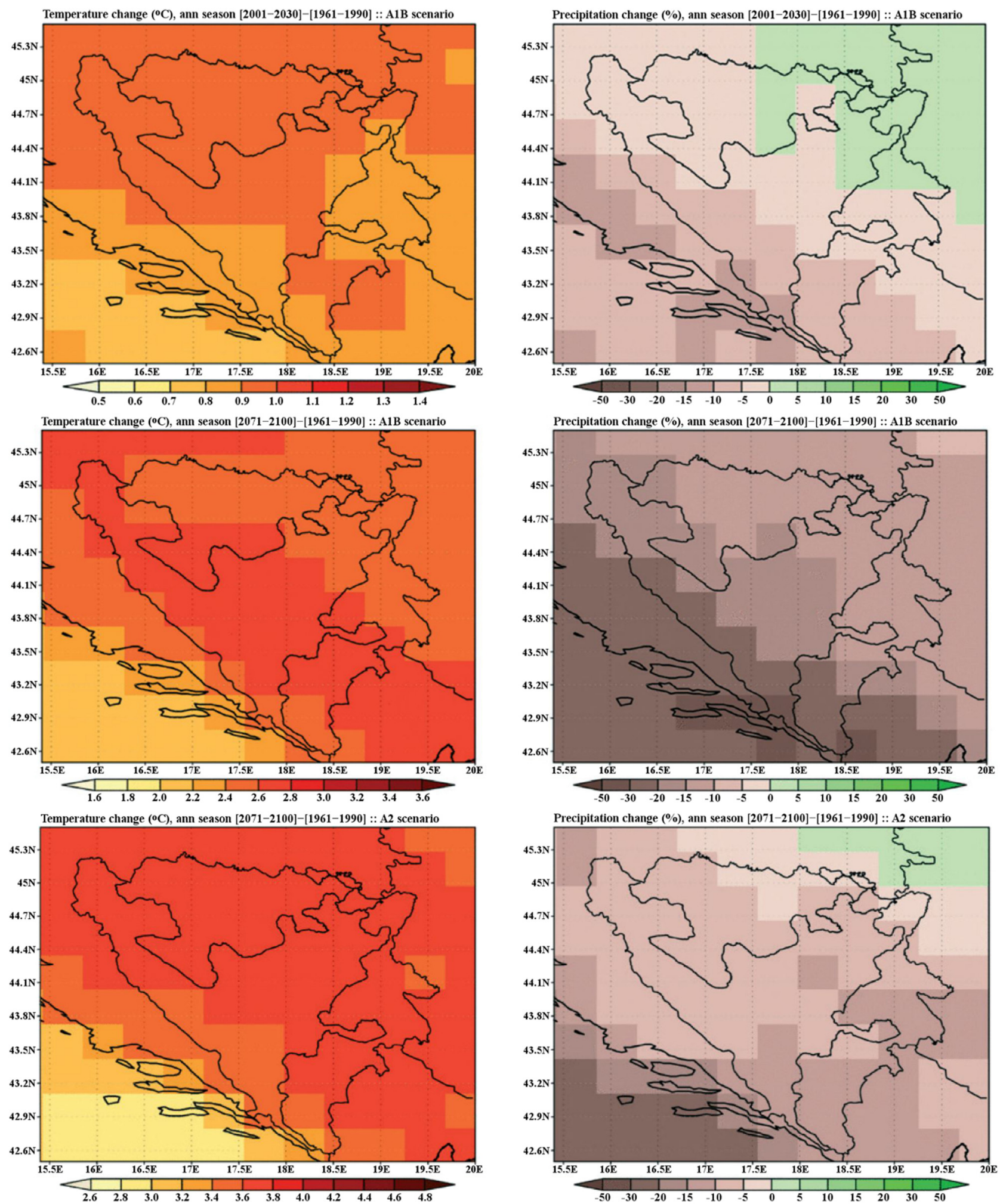

Figure 4. Temperature and precipitation projections for Bosnia and Herzegovina. Source: [3].

\subsection{Recent Extreme Climate Events}

Drought is a frequent adverse climatic event over the last decade in the Western Balkan and $\mathrm{BH}$. Six drought periods were registered in past 14 years, resulting in enormous economic losses in agriculture. The extreme drought in 2012 was the culmination of a longer dry period, which resulted in a water supply crisis due to lowered water levels of rivers and groundwater. It is estimated that only in 
2012, the drought periods caused losses of over USD 1 billion in agricultural production and yield reduction up to $70 \%$ [34]. The most affected was maize production, which is the main raw material in production of animal feed. Similar losses were found in production of barley, soybeans, alfalfa, clover, beans, meadows and pastures, which led to a lack of fodder. Lack of fodder influenced the reduction in the number of livestock and livestock production, production of milk and meat supply to the domestic market. At the same time, the effects of the drought have affected rises in food prices, and reduced the export of products. Current projections of drought impact on crop yields remain uncertain due to lack of research in this area. However, it is certain that this issue should not be ignored, taking into account the existing research. Research conducted in northeast Bosnia indicates the severity of the problems facing the country when it comes to the extension of drought periods and changes in precipitation distribution. Using climate, soil and crop data, the estimated average yield reduction in rain-fed agriculture for the six most common crops in the region for past five decades was $3.8 \%-20.6 \%$ and $9.3 \%-27.7 \%$ on loamy and heavy soil, respectively [35]. There is a big difference when the yield reduction from the last decade is compared to the rest of the research period, due to increased air temperature, precipitation, wind speed and lower relative air humidity. Most notably, the maize yield reduction in the past decade was $184 \%$ higher compared to the earlier period.

Flood is the other frequent major natural hazard related to weather and climate change in BH. In 2004, flooding affected over 300,000 people in 48 municipalities, destroyed 20,000 ha of farmland, washed away several bridges, and contaminated drinking water. In 2010, BH experienced the largest amount of precipitation recorded to that moment, which resulted in massive floods on the entire territory [36]. The flooding situation culminated with an extraordinary rainfall in May 2014, surpassing even the flood levels from 2010, affecting BH and the surrounding countries. The whole watershed of river Sava, the largest watershed in $\mathrm{BH}$ (67\% of the total territory) was overflooded with the accumulated downstream flow of water, mud and debris, causing widespread floods in the plain. Breaches of embankments resulted in flash floods and the rivers carrying debris downstream created a path of destruction and desolation [37]. Early estimates indicate that 81 local government units suffered damages, losses, as well as social or environmental impacts to varying degrees. Around 90,000 people were temporarily displaced from their homes and more than 40,000 took extended refuge in public or private shelters. The floods in 2014 caused the damage equivalent to nearly $15 \%$ of GDP (cca 2.6 billion USD).

\subsection{Impact of Climate Change on Agricultural Systems}

There exist no detailed information concerning impact of climate change in BH. However, it is well documented that climate change and increased variability will lead to changes in land and water regimes, and thus have a direct impact on agriculture in the region [38] (Table 2). The impacts of climate change on agriculture are primarily reflected in changes in mean temperatures and precipitation, which subsequently lead to yield reduction and the emergence of new pathogens and diseases, crop failures long-term production declines [39]. Climate change will have different effects on agricultural systems in Europe, with likely increases in crop yields and ranges of grown crops in the north, while a significant decrease in yields are expected in the South [40]. The actual impacts of climate change depend greatly on the adaptive capacity of an affected system, region, or community to cope with the impacts and risks of climate change, which is again determined by its socioeconomic characteristics [41]. The response of 
crop yields to climate change varies widely, depending on agro climatic zones, species, cultivar, soil conditions, $\mathrm{CO}_{2}$ level and other location factors [42]. Vulnerability of the agricultural sector in $\mathrm{BH}$ is characterised through appearance and frequency of droughts and floods, which can cause a significant yield loss or reduction.

It is expected that the duration of dry periods, the incidence of torrential flooding and intensity of soil erosion will increase during this century. In addition, a higher incidence of hail, storms and increased maximum wind speed may pose a threat to all forms of human activity [7]. This will significantly affect the water balance in soil and underground, as the increased intensity of rainfall and frequent episodes of rapid melting of snow increases the amount of water flowing over the surface and steep slopes of the mountains [3]. The result of this will be yield reductions due to reduced precipitation and increased evaporation, potentially reducing the productivity of livestock and increased incidence of pests and diseases of agricultural crops [43]. However, due to the extended vegetation period, growing seasons will be extended, with increasing potential for growing a wider range of crops.

\subsection{Climate Institutions}

As a signatory to UNFCCC and the Kyoto Protocol, BH is obliged to develop strategies for climate change mitigation and adaptation to changing climatic conditions, to cooperate in climate observations, research and technology transfers and to raise public awareness. It was quiet on the climate change front up until 2009, when the Initial National Communication of BH (INCBiH) under UNFCCC were published. The main objective of the INCBiH was to make an inventory of greenhouse gas emissions in line with UNFCCC reporting guidelines, which were available only for 1990 at the time. Besides the GHG inventory, the document also proposed some preliminary findings on climate change scenarios and their impact on different sectors [33]. The Second National Communication (SNCBiH) followed in 2012, which updated GHG inventory period (1991-2001), as well as vulnerability of main sectors and estimated potentials for mitigating climate change [3]. What is more important, the Climate Change Adaptation and Low-Emission Development Strategy for BH has been developed alongside SNCBiH. Although defined as the initial strategy, requiring more reliable data and additional development during the course of its implementation, it shows the political will towards building necessary capacities and policies towards low-emission and climate resilient development [44]. The strategy regards water resources and agriculture as the major priorities, which affect the other sectors to a greater or lesser extent and present some concrete activities and outputs, together with indicators, indicative budget and timeframe. Defining agriculture as a priority sector, along with the future integration of adaptation and mitigation measures in the agricultural strategic documents and the adequate funding, creates fertile ground for the realization of activities related to adaptation to climate change in agriculture proposed in the next section. 
Table 2. Climate change impacts on agriculture in Western Balkan.

\begin{tabular}{|c|c|c|c|c|}
\hline Nr. & Climate Change Variable & Impact & Country/Region & Source \\
\hline 1 & $\begin{array}{l}\text { Change in temperature and rainfall according to } \\
\text { IPCC A1B and A2 scenarios }\end{array}$ & $\begin{array}{l}\text { A1B (2001-2030) change in yields: winter wheat }(-16 \% \\
\text { to } 21 \%) \text {; maize (-6\% to } 71 \%) \text {; maize, irrigated }(-5 \% \text { to } \\
6 \%) \text {; soybeans, irrigated ( } 21 \%-67 \%) \\
\text { A2 }(2071-2100) \text { : winter wheat }(-10 \% \text { to } 6 \%) ; \\
\text { maize ( }-52 \% \text { to }-22 \%) \text {; maize, irrigated }(-7 \% \text { to } 4 \%) ; \\
\text { soybeans, irrigated ( }-9 \% \text { to } 43 \%)\end{array}$ & Serbia & [45] \\
\hline 2 & $\begin{array}{l}\text { Mean relative changes in water-limited crop yield simulated by } \\
\text { the ClimateCrop model for the 2050s compared with 1961- } \\
1990 \text { for } 12 \text { different climate models projections under the } \\
\text { A1B scenario. }\end{array}$ & $\begin{array}{l}\text { Projected changes in water-limited crop yield } \\
\text { from } 5 \% \text { to }-25 \%\end{array}$ & Western Balkan & [46] \\
\hline \multirow[t]{2}{*}{3} & $\begin{array}{l}\text { Rain-fed yield reduction in vulnerable areas calculated with } \\
\text { FAO Crop Yield Response to Water Deficit using different } \\
\text { IPCC SRES scenarios (2025-2100) }\end{array}$ & $\begin{array}{c}\text { Yield reduction } \\
\text { Vinegrape } 46 \%-59 \% \\
\text { Tomato } 72 \%-84 \% \\
\text { Winter wheat } 8 \%-25 \% \\
\text { Alfalfa } 58 \%-70 \% \\
\text { Apple } 46 \%-59 \%\end{array}$ & \multirow[t]{2}{*}{ FYR Macedonia } & \multirow[t]{2}{*}{ [47] } \\
\hline & $\begin{array}{l}\text { Cost of decreased production } \\
\text { (million EUR—current prices) }\end{array}$ & $\begin{array}{l}\text { Winter wheat } 4.1(2025)-8.6(2100) \\
\text { Vinegrape } 18.2(2025)-23.4(2100) \\
\text { Alfalfa } 7.0(2025)-8.5(2100) \\
\end{array}$ & & \\
\hline 4 & $\begin{array}{l}\text { Impact of a } 2{ }^{\circ} \mathrm{C} \text { global temperature rise on Mediterranean } \\
\text { region according to HadCM3 simulation and CROPSYST crop } \\
\text { simulation model }\end{array}$ & $\begin{array}{c}\text { Significant yield decrease for all researched crops } \\
\text { (legumes, C3 summer crops, tuber crops, cereals) except } \\
\text { C4 summer crops }\end{array}$ & $\begin{array}{l}\text { Mediterranean region } \\
\quad \text { (Serbia grid cell) }\end{array}$ & [48] \\
\hline
\end{tabular}




\section{Policy Implications of Climate Change}

The global challenges of adaptation to climate change in agriculture are many. The core challenge is to produce more food by using less resources, under changing production conditions and with net reduction in greenhouse gas emissions [49]. The extent of sustainable adaptation depends on the adaptive capacity, knowledge, skills, robustness of livelihoods and alternatives, resources and institutions accessible to enable undertaking effective adaptation [50]. Extreme weather events, such as increased intensity of droughts, frequency of heat waves, heavy precipitation events resulting in the floods and landslides, are becoming increasingly more frequent [51]. These events have significant impacts on both human lives and national economies and are expected to continue to increase in the future if we do not take sufficient actions. Extreme weather events have the potential to reverse development progress and entrench poverty, especially in developing countries like $\mathrm{BH}$, characterized by limited social safety nets, lack of access to markets, capital, assets, or insurance mechanisms [52]. Below, we highlight relevant socio-political and technological processes that should be the basis for further strategic planning and development of necessary institutions in $\mathrm{BH}$. These processes should address adequately the problem of climate change in agriculture.

\subsection{Policy and Research Capacity}

Significant difficulties for the agricultural sector in $\mathrm{BH}$ arise from the state's constitutional order, according to which all established levels of government - from national to municipal - have the authority for planning and management in agriculture. This sort of organization on the one hand does not allow for the establishment of functional coordinated networks of institutions, and on the other hand it leads to unnecessary and costly multiplications of institutions of the same or similar domains [8]. The unanimous attitude of most sectoral interest groups and non-governmental organizations is that $\mathrm{BH}$ needs a national Ministry of Agriculture, formation of which would represent a possible way to better coordinate agricultural policies and consistent articulation of the interests of the sector in international relations (especially in the process of joining with EU), as well as easier establishing the necessary information systems and registers [28]. The agricultural sector is already facing many challenges, which will be further exacerbated by increased frequency and severity of extreme weather events, eventually leading to increased vulnerability. Climate change is a global challenge whose environmental impacts knows no boundaries or borders. Only the unified stance and common policy will lead to effective coordination and harmonisation in terms of implementation of adaptation and mitigation measures in agriculture and all other vulnerable sectors.

Assessment of vulnerability to climate change is an important tool for the analysis and presentation of data at a national level, where the current and potential consequences of climate change are presented to stakeholders in a convenient way and serve as a base for further adaptation policy decisions [53]. The process of adaptation begins with an assessment of the different dimensions of vulnerability and the range of potential options for action, including their justification. A top-down approach is derived from global climate projections, which is further downscaled and applied to assess regional impacts of climate change, while the bottom-up approaches include the involvement of the population and stakeholders of the system in identifying climate-change stresses, impacts and adaptive strategies [54]. In terms of 
agriculture, assessment of agricultural vulnerability to climate change should lead to identification of particularly vulnerable regions and agricultural production systems, which should further lead to choice of specific adaptation measures and resource allocation for adaptation.

$\mathrm{BH}$ needs to have the political and scientific knowledge and public support to adapt to climate change. Investment in agricultural research and development has been declining, or stagnating at best, thus creating a knowledge gap between low and high-income countries [55]. It is crucial to take a long-term, strategic view and to conduct research in order to meet future climate challenges and to develop approaches to facilitate transfer of new knowledge and technologies into practical application. Extension services have played a key role in promoting agricultural productivity and dissemination of knowledge and their role in promoting adaptation measures to climate change will certainly have the same importance [56,57]. Therefore, it is necessary to strengthen the capacity of underdeveloped public agricultural extension services, enabling them to take leading role in terms of strengthening innovation process, building linkages between farmers and other agencies, and institutional development. Research institutes and agricultural universities as a country's leaders in knowledge generation need to create linkages and provide direct transfer of information by educating extension workers regarding the advantages and potential technologies and practices. This can be accomplished on different ways, such as demonstration fields, joint research projects, field trials, training seminars etc. [58].

\subsection{Technological Development}

Efforts to reduce vulnerability to climate change must include strengthening of adaptive capacity and resilience of rural communities. Such strategies will enable farmers to achieve food security and increased well-being under current climatic conditions and will directly contribute to increasing their ability to cope with future uncertainty. More productive and resilient agriculture requires a major shift in the way land, water, soil nutrients and genetic resources are managed to ensure that these resources are used more efficiently and sustainably [59]. Making this shift will require considerable changes in national and local governance, legislation, policies and financial mechanisms. The elements of this categorization include mechanical, biological, chemical, agronomic, biotechnological, and informational innovations [60]. Production that is more efficient and creates more opportunities and access to broader markets can boost smallholders' resilience and create sustainable livelihoods while helping to meet growing demand for food.

Development of new high yielding, input use-efficient, abiotic and biotic stress-resistant varieties with enhanced traits better suited to adapt to climate change is crucial for agricultural adaptation to climate change. Activities and research on plant genetic resources in BH started during eighties of last century, within a project called the "Gene Bank of Yugoslavia". Unfortunately, most of the documents from that period went missing or were destroyed during the last war. Activities such as ex situ and in situ inventory and conservation of plant genetic resources for agriculture have been restarted during the beginning of this century with the help of international donors [61]. After the inventory and identification of local genotypes, the next step should be linking the selection process with the other stakeholders by employing participatory techniques in order to improve the effectiveness and impact of agricultural research. Having farmers and other stakeholders involved in the development of varieties 
through participatory plant breeding $[62,63]$ may lead quick and cost-effective production of new breeds and varieties of crops adapted to local needs.

Weather and climate information systems, including early warning systems, aim to reduce vulnerability and improve response capacities of those at risk by increasing their preparedness [64]. Prompt identification of a risk and communication can enable timely responses and assist in farm level adaptation. Farmers should use present and future climate-related information to plan and manage weather risks, maximize productivity, and minimize the environmental impacts of farming practices. Information from the network of agro-monitoring stations combined with remotely sensed information, enable the development of biophysical models used to estimate weather conditions, soil and nutrient status, crop water needs, soil erosion, pest and disease emergence, choice of crop variety best suited for local conditions, etc. [65]. Therefore, strengthening of technologies, human resources and development of monitoring, warning and forecasting networks related to hydrological, meteorological, climatic and environmental risks should be considered as one of the priorities.

Global climate change will continue to lead towards significant changes in annual precipitation patterns in south-eastern Europe. In such circumstances, irrigation can certainly be one of the key mechanisms of adaptation in agriculture. There exists no available data on irrigated areas or crops in $\mathrm{BH}$. The total irrigated area according to unofficial data is only $0.4 \%$ of arable land, which is considerably less than in neighbouring countries, especially EU [66]. In this situation, irrigation is a measure that can reduce the problems of critical drought periods by improving and stabilizing yields. Due to the documented water deficits and the growing incidences of drought, irrigation should settle around 33\% annual water needs for plants in south, $14 \%$ in north and $8 \%$ in central BH [67]. These needs will increase further according to future climate projections for $\mathrm{BH}$, which include extension of vegetation period, increased frequency of extreme temperatures and longer frost-free periods, leading to additional increase in evapotranspiration and reduced soil moisture content $[43,68]$. The agricultural sector needs the support and cooperation of other sectors in order to operate in a sustainable manner and follow the principles of integrated water management. Public and private investments in irrigation would enable the expansion of irrigated areas and irrigation use as a supplement to rain-fed agriculture in order to stabilize and increase yields.

\section{Conclusions}

We have reviewed the agricultural sector in Bosnia and Herzegovina and the likely impacts of climate change upon it. We have also proposed policy options to optimize opportunities and mitigate consequences of climate change. We conclude that $\mathrm{BH}$ is a country rich in natural resources and biodiversity, and large parts of the country possess a favourable climate for agricultural production. However, despite such endowments, the agricultural sector is hampered by low productivity, extensive farming practices and technologies, carried out on small and fragmented farms. This is further exacerbated by a weak and inefficient agrarian policy and legislation, low budget allocations for agriculture, inadequate market access and a general lack of information and knowledge.

The legacy of the past socio-political system and the current complex political structure have significant consequences for the agricultural development. Agriculture is highly vulnerable to climate change. Higher temperatures and changes in precipitation are reducing crop yields and increasing the 
likelihood of short-term crop failures and long-term production declines. Bosnia and Herzegovina, as well as other Mediterranean countries in southern and south-eastern Europe, are expected to experience significant agricultural production losses. As a country that is a potential candidate for the EU-membership, $\mathrm{BH}$ needs to implement reforms in the agricultural and rural development sectors in order to reduce the significant policy gap compared to other European countries. In order to cope with the challenges of climate change and climate variability, it is imperative to raise the political awareness and increase recognition on all governmental levels about the impeding threats of climate change on the agricultural sector. The literature on climate change impacts and vulnerability in the agricultural sector stresses the importance of adaptation and urgency to implement adaptation and mitigation measures. The recently published Climate Change Adaptation and Low-Emission Development Strategy for BH shows that there is a political will to build necessary capacities and policies towards low-emission and climate resilient development. We addressed some of the relevant socio-political and technological processes that should be the basis for further strategic planning and institutions that are needed to create the capacity to address climate change in agriculture, agricultural development, knowledge transfer and implementation. Most of them require significant funds and time for their implementation. However, it is unlikely that the agricultural sector alone will be able to cope with the process of adaptation. Only the development of a favorable environment together with political, institutional, economic, social and other actors will lead to a successful agricultural adaptation to climate change.

\section{Acknowledgments}

This study is supported by the project "Agricultural Adaptation to Climate Change-Networking, Education, Research and Extension in the West Balkans", funded by HERD_Programme for Higher Education, Research and Development 2010-2014.

Special thanks to Melisa Ljusa from the Faculty of Agriculture and Food Sciences, University of Sarajevo, for providing valuable insights on the history of agricultural development in Bosnia and Herzegovina.

The authors would like to thank the anonymous reviewers for their helpful and constructive comments.

\section{Conflicts of Interest}

The authors declare no conflict of interest.

\section{References}

1. Brooks, N.; Adger, W.N.; Kelly, P.M. The determinants of vulnerability and adaptive capacity at the national level and the implications for adaptation. Glob. Environ. Chang. 2005, 15, 151-163.

2. Kreft, S.; Eckstein, D. Global Climate Risk Index 2014; Germanwatch: Bonn, Germany, 2013.

3. UNFCCC. Second National Communication of Bosnia and Herzegovina under the United Nation Framework Convention on Climate Change (SNCBIH); Available online: http://www.ba.undp.org/ content/bosnia_and_herzegovina/en/home/library/environment_energy/sncbih-2013.html (accessed on 2 July 2014). 
4. Smit, B.; Skinner, M.W. Adaptation options in agriculture to climate change: A typology. Mitig. Adapt. Strateg. Glob. Chang. 2002, 7, 85-114.

5. Eriksen, S.; Aldunce, P.; Bahinipati, C.S.; Martins, R.D.A.; Molefe, J.I.; Nhemachena, C.; O’Brien, K.; Olorunfemi, F.; Park, J.; Sygna, L.; et al. When not every response to climate change is a good one: Identifying principles for sustainable adaptation. Clim. Dev. 2011, 3, 7-20.

6. South East European Forum on Climate Change Adaptation (SEEFCCA). Climate Vulnerability Assessment: Serbia; SEEFCCA: Belgrade, Serbia, 2012.

7. Custovic, H.; Djikic, M.; Ljusa, M.; Zurovec, O. Effect of climate changes on agriculture of the western Balkan countries and adaptation policies. Agric. For. 2012, 58, 127-141.

8. Federal Ministry of Agriculture Water Management and Forestry. Medium term development strategy of agricultural sector in Federation of Bosnia and Herzegovina for 2014-2018; Federal Ministry of Agriculture Water Management and Forestry: Sarajevo, Bosnia and Herzegovina, 2013.

9. Kamberović, H. Osnovna obilježja razvoja društva u Bosni i Hercegovini od 1945 do 1953. Časopis Suvrem. Povijest 1998, 30, 359-376.

10. Golić, B. Bosanskohercegovačka ekonomija od ZAVNOBIH-a do Daytona. Academy of Sciences and Arts of Bosnia and Herzegovina, Spec. Publ. 2007, 37, 162-177.

11. Kamberović, H. Karakteristike društva u Bosni i Hercegovini neposredno nakon drugog svjetskog rata. Academy of Sciences and Arts of Bosnia and Herzegovina, Spec. Publ. 2007, 37, 214-227.

12. Katz, V. Društveni i ekonomski razvoj Bosne i Hercegovine (1945-1953); Institut za istoriju: Sarajevo, Bosnia and Herzegovina, 2001.

13. Simon, D. Development revisited: Thinking about, practicing and teaching development after the Cold War. In Development as Theory and Practice: Current Perspectives on Development and Development Cooperation; Simon, D., Narman, A., Eds.; Routledge: London, UK, 1999, pp. 17-54.

14. Nurković, R. Distribution of industry in Bosnia and Herzegovina. Glasnik ZRS Koper 2008, 8, 67-69.

15. Mirjanić, S. Poljoprivredno Zemljište u Društvenom Planu Republike, Savjetovanje o Temi Zemljište u prostornom planu SR BiH; Poljoprivredni Fakultet: Sarajevo, Bosnia and Herzegovina, 1983.

16. Selak, V. Potražnja hrane i zemljišni prostor u SR BiH, Savjetovanje o Temi Zemljište u Prostornom Planu SR BiH; Poljoprivredni Fakultet: Sarajevo, Bosnia and Herzegovina, 1983.

17. Marinković, G. Stvaranje državne i društvene svojine na području Srbije i bivše Jugoslavije. Zbornik Radova Građev. Fakulteta 2012, 21, 135-147.

18. Mizik, T. A snapshot of western Balkan's agriculture from the perspective of EU accession. Stud. Agric. Econ. 2012, 114, 39-48.

19. Puljiz, V. Eksodus poljoprivrednika; Centar za sociologiju sela, grada i prostora Instituta za društvena istraživanja Sveučilišta u Zagrebu: Zagreb, Yugoslavia, 1977.

20. Žimbrek, T. Agrarna politika-izabrana predavanja; Agronomski fakultet Sveučilišta u Zagrebu: Zagreb, Croatia, 2008.

21. Ivankovic, M.; Bojnec, S.; Kolega, A.; Selak, V. Economic and social role of agriculture in the Federation of Bosnia and Herzegovina. J. Gen. Soc. Issues 2006, 15, 84-85. 
22. Ministry of Foreign Trade and Economic Relations (MoFTER). Agriculture Report for Bosnia and Herzegovina for 2012; Ministry of Foreign Trade and Economic Relations (MoFTER): Sarajevo, Bosnia and Herzegovina, 2012.

23. European Bank for Reconstruction and Development (EBRD). Transition Report 2013; Available online: http://www.ebrd.com/news/publications/transition-report/transition-report-2013.html (accessed on 7 October 2014)

24. Agency for Statistics of Bosnia and Herzegovina (BHAS). Bosnia and Herzegovina in figures-Statistical Bulletin; Agency for Statistics of Bosnia and Herzegovina (BHAS): Sarajevo, Bosnia and Herzegovina, 2013.

25. Agency for Statistics of Bosnia and Herzegovina (BHAS). Structure of agricultural land in Bosnia and Herzegovina. Unpublished data, available on request; Sarajevo, Bosnia and Herzegovina, 2014.

26. Agency for Statistics of Bosnia and Herzegovina (BHAS). Harvested area, total production and yield of main crops, Statistical Bulletin; Agency for Statistics of Bosnia and Herzegovina (BHAS): Sarajevo, Bosnia and Herzegovina, 2014.

27. Ministry of Foreign Trade and Economic Relations (MoFTER). Competitiveness assessment of three agribusiness value-chains in Bosnia and Herzegovina; Anteja ECG: Ljubljana, Slovenia, 2012.

28. Green Council. Establishment of the BiH Ministry of agriculture, food and rural Development and other Structures as a way of achieving economic progress for BiH in the EU integration process; Green Council: Sarajevo, Bosnia and Herzegovina, 2013.

29. FAOSTAT. Compare data tool-Production. Available online: http://faostat3.fao.org/compare/E (accessed on 8 December 2014).

30. Alibegovic-Grbic, S.; Civic, H.; Cengic, S.; Muratovic, S.; Dzomba, E. Effect of weather conditions, stage of plant growth and $\mathrm{N}$ application on yield and quality of grassland in Bosnia and Herzegovina. In Land use systems in grassland dominated regions. Proceedings of the 20th General Meeting of the European Grassland Federation, Luzern, Switzerland, 21-24 June 2004, pp. 897-899.

31. European Comission (EC). Bosnia and Herzegovina country report; Arcotrass GmbH: Germany, 2006.

32. World Bank. Agricultural sector policy note for Bosnia and Herzegovina-Trade and integration policy notes; World Bank: Washington, DC, USA, 2010.

33. UNFCCC. Initial National Communication of Bosnia and Herzegovina under the United Nation Framework Convention on Climate Change (INCBIH); Ministry for Spatial Planning, Construction and Ecology of Republic of Srpska: Banja Luka, Bosnia and Herzegovina, 2009.

34. Hodzic, S.; Markovic, M.; Custovic, H. Drought conditions and management strategies in Bosnia and Herzegovina-Concise country report. Available online: http:/www.ais.unwater.org/ais/ pluginfile.php/548/mod_page/content/72/Bosnia_Herzegovina_CountryReport.pdf (accessed on 11 September 2014)

35. Zurovec, J.; Cadro, S. Climate changes, the need and importance of crop irrigation in northeastern Bosnia and Herzegovina. In Proceedings of the 21st Scientific-Expert Conference in Agriculture and Food Industry, Neum, Bosnia and Herzegovina, 29 September 2010-2 October 2 2010; pp. 705-716. 
36. International Fund for Agricultural Development (IFAD). Environmental and climate change assessment-Bosnia and Herzegovina. Available online: http://www.ifad.org/climate/resources. htm (accessed on 7 September 2014)

37. European Comission (EC). Bosnia and Herzegovina recovery needs assessment, floods 14-19 May_Executive summary. Available online: http://ec.europa.eu/enlargement/pdf/press_corner/ floods/rna-executive-summary.pdf (accessed on 11 September 2014).

38. Kurukulasuriya, P.; Rosenthal, S. Climate Change and Agriculture: A Review of Impacts and Adaptations. Climate Change Series 91. Environment Department Papers; World Bank: Washington, DC, USA, 2013.

39. Nelson, G.C.; Rosegrant, M.W.; Koo, J.; Robertson, R.; Sulser, T.; Zhu, T.; Ringler, C.; Msangi, S.; Palazzo, A.; Batka, M. Climate Change: Impact on agriculture and costs of adaptation. International Food Policy Research Institute, Washington, DC, USA, 2009.

40. Alcamo, J.; Moreno, J.M.; Nováky, B.; Bindi, M.; Corobov, R.; Devoy, R.J.N.; Giannakopoulos, C.; Martin, E.; Olesen, J.E.; Shvidenko, A. Europe. In Climate Change 2007: Impacts, Adaptation and Vulnerability. Contribution of Working Group II to the Fourth Assessment Report of the Intergovernmental Panel on Climate Change; Parry, M.L., Canziani, O.F., Palutikof, J.P., van der Linden, P.J., Hanson, C.E., Eds.; Cambridge University Press: Cambridge, UK, 2007; pp. 541-580.

41. Smit, B.; Pilifosova, O. Adaptation to climate change in the context of sustainable development and equity. Sustain. Dev. 2003, 8, 9.

42. Thornton, P.K.; Jones, P.G.; Alagarswamy, G.; Andresen, J. Spatial variation of crop yield response to climate change in east Africa. Glob. Environ. Chang. 2009, 19, 54-65.

43. Bär, R.; Rouholahnejad, E.; Rahman, K.; Abbaspour, K.C.; Lehmann, A. Climate change and agricultural water resources: A vulnerability assessment of the Black Sea catchment. Environ. Sci. Policy 2015, 46, 57-69.

44. Council of Ministers of $\mathrm{BiH}$. Climate change adaptation and low-emission development strategy for Bosnia and Herzegovina. Available online: http://www.ba.undp.org/content/bosnia_and_ herzegovina/en/home/library/environment_energy/climate-change-adaptation-and-low-emissiondevelopment-strategy-/ (accessed on 9 August 2014).

45. Mihailović, D.T.; Lalić, B.; Drešković, N.; Mimić, G.; Djurdjević, V.; Jančić, M. Climate change effects on crop yields in Serbia and related shifts of Köppen climate zones under the SRES-A1B and SRES-A2. Available online: http://onlinelibrary.wiley.com/doi/10.1002/joc.4209/abstract (accessed on 11 September 2014).

46. Iglesias, A.; Quiroga, S.; Diz, A. Looking into the future of agriculture in a changing climate. Eur. Rev. Agric. Econ. 2011, 38, 427-447.

47. The Regional Environmental Center for Central and Eartern Europe (REC). The impacts of climate change on food production in the western Balkan region. Available online: $\mathrm{http}$ ://documents.rec.org/topic-areas/Impacts-climage-change-food-production.pdf (accessed on 13 September 2014)

48. Giannakopoulos, C.; Bindi, M.; Moriondo, M.; LeSager, P.; Tin, T. Climate change impacts in the mediterranean resulting from a $2{ }^{\circ} \mathrm{C}$ global temperature rise. WWF: Gland, Switzerland, 2005. 
49. Lybbert, T.J.; Sumner, D.A. Agricultural technologies for climate change in developing countries: Policy options for innovation and technology diffusion. Food Policy 2012, 37, 114-123.

50. IPCC. Climate Change 2007: Synthesis Report. Contribution of Working Groups I, II and III to the Fourth Assessment Report of the Intergovernmental Panel on Climate Change, Core Writing Team; Pachauri, R.K., Reisinger, A., Eds.; IPCC: Geneva, Switzerland, 2007; p. 104.

51. IPCC. Special Report-Managing the Risks of Extreme Events and Disasters to Advance Climate Change Adaptation; Cambridge University Press: New York, NY, USA, 2011.

52. Shepherd, A.; Mitchell, T.; Lewis, K.; Lenhardt, A.; Jones, L.; Scott, L. Muir-Wood, R. Full Report: Geography of Disasters, Poverty and Climate Extremes in 2030; ODI: London, UK, 2013.

53. Füssel, H.-M.; Klein, R.J.T. Climate change vulnerability assessments: An evolution of conceptual thinking. Clim. Chang. 2006, 75, 301-329.

54. Dessai, S.; Hulme, M. Does climate adaptation policy need probabilities? Clim. Policy 2004, 4, 107-128.

55. Beddington, J.; Asaduzzaman, M.; Clark, M.; Bremauntz, A.; Guillou, M.; Jahn, M.; Lin, E.; Mamo, T.; Negra, C.; Nobre, C.; et al. The role for scientists in tackling food insecurity and climate change. Agric. Food Secur. 2012, 1, 10.

56. Maponya, P.; Mpandeli, S. The role of extension services in climate change adaptation in Limpopo province, South Africa. J. Agric. Ext. Rural. Dev. 2013, 5, 137-142.

57. Bryan, E.; Deressa, T.T.; Gbetibouo, G.A.; Ringler, C. Adaptation to climate change in Ethiopia and South Africa: Options and constraints. Environ. Sci. Policy 2009, 12, 413-426.

58. FAO. Management of Agricultural Research: A Training Manual. Module 8: Research-Extension Linkage; FAO: Rome, Italy 1997.

59. FAO. Climate-smart agriculture sourcebook. Available online: http://www.fao.org/climatechange/ climatesmart/en/ (accessed on 12 November 2014).

60. Sunding, D.; Zilberman, D. The agricultural innovation process: Research and technology adoption in a changing agricultural sector. Handb. Agric. Econ. 2001, 1, 207-261.

61. FAO. Country Report on the State of Plant Genetic Resources for Food and Agriculture-Bosnia and Herzegovina; FAO: Rome, Italy, 2010.

62. Witcombe, J.R.; Joshi, K.D.; Gyawali, S.; Musa, A.M.; Johansen, C.; Virk, D.S.; Sthapit, B.R. Participatory plant breeding is better described as highly client-oriented plant breeding. I. Four indicators of client-orientation in plant breeding. Exp. Agric. 2005, 41, 299-319.

63. Mba, C.; Guimaraes, E.; Ghosh, K. Re-orienting crop improvement for the changing climatic conditions of the 21st century. Agric. Food Secur. 2012, 1:7.

64. Hogarth, J.R.; Campbell, D.; Wandel, J. Assessing human vulnerability to climate change from an evolutionary perspective. In Reducing Disaster: Early Warning Systems for Climate Change; Singh, A., Zommers, Z., Eds.; Springer: Netherlands 2014; pp. 63-87.

65. Weiss, A.; Van Crowder, L.; Bernardi, M. Communicating agrometeorological information to farming communities. Agric. For. Meteorol. 2000, 103, 185-196.

66. Siebert, S.; Döll, P.; Hoogeveen, J.; Faures, J.M.; Frenken, K.; Feick, S. Development and validation of the global map of irrigation areas. Hydrol. Earth Syst. Sci. 2005, 9, 535-547.

67. Vlahinic, M. Hydro accumulation, agriculture, and land and water management in Bosnia and Herzegovina. Voda i mi 2000, 27, 26-37. 
68. Bazzaz, F.; Sombroek, W. Global climate change and agricultural production. Direct and indirect effects of changing hydrological, pedological and plant physiological processes; FAO and John Wiley \& Sons: London, UK, 1996.

(C) 2015 by the authors; licensee MDPI, Basel, Switzerland. This article is an open access article distributed under the terms and conditions of the Creative Commons Attribution license (http://creativecommons.org/licenses/by/4.0/). 